\title{
PENGELOMPOKKAN KUALITAS DAGING IKAN TUNA DENGAN K-MEANS BERBASIS HISTOGRAM DERAJAT KEABUAN
}

\author{
Roys Pakaya ${ }^{1)}$, Salman Suleman ${ }^{2)}$ \\ 1,2 Program Studi Teknik Informatika, Politeknik Gorontalo \\ Email: royspakaya@poligon.ac.id ${ }^{1)}$
}

\begin{abstract}
ABSTRAK
Potensi perikanan dan kelautan Gorontalo yang paling menonjol adalah ikan tuna yang merupakan hasil tangkapan nelayan. Dinas Kelautan dan Perikanan (DKP) melakukan berbagai terobosan sehingga nelayan khususnya yang menangkap ikan tuna bisa sejahtera dengan tujuan untuk meningkatkan kualitas hasil perikanan. Kualitas ikan tuna tangkapan nelayan Gorontalo memiliki kualitas dan mutu yang bagus, hal ini terlihat oleh banyaknya permintaan dari daerah tetangga. Saat ini produksi tuna hasil tangkapan nelayan di Gorontalo dikirim ke sejumlah daerah seperti Makassar, Surabaya, Jakarta, dan Bali. selanjutnya ikan tuna ini diekspor keluar negeri, hal ini disebabkan seringnya terjadi perbedaan dalam mengelompokan kualitas daging ikan tuna. Dalam mengetahui mutu dan kualitas hasil perikanan, khusunya ikan tuna dapat dilihat secara langsung. Tahapan ini dilakukan oleh seorang ahli (checker) dengan melakukan pembedahan pada ikan tuna. Ikan tuna akan dibedah menjadi empat bagian daging yaitu daging sisi kiri dan kanan. Namun dalam pengelompokan mutu dan kualitas daging ikan tuna dengan menggunakan cara ini sering terjadi banyak kesalahan.

Pada penelitian ini penulis menggunakan metode clustering K-Means berbasis histogram derajat keabuan untuk menyelesaikan masalah dalam pengelompokan kualitas daging ikan tuna. Hasil clustring diperoleh 3 kelompok kualitas daging ikan tuna yaitu Cluster A, Cluster B, Cluster C.
\end{abstract}

\section{Kata kunci: Pengelompokan, kualitas daging ikan tuna, K-Means}

\section{ABSTRACT}

Gorontalo's most prominent fisheries and marine resources are tuna which are caught by fishermen. The Marine and Fisheries Service (DKP) made various breakthroughs so that fishermen, especially those who catch tuna, can prosper in order to improve the quality of fishery products. The quality of tuna fish caught by Gorontalo fishermen has good quality and quality, this is evident by the many requests from neighboring regions. Currently tuna production from fishermen in Gorontalo is sent to a number of areas such as Makassar, Surabaya, Jakarta and Bali. Furthermore, these tuna fish are exported abroad, this is due to the frequent differences in classifying the quality of tuna meat. In knowing the quality and quality of fishery products, especially tuna can be seen directly. The sorting stage is carried out by an expert (checker) by performing surgery on tuna. Tuna fish will be dissected into four parts of meat, namely the left and right sides of the meat. However, in grouping the quality and quality of tuna meat using this method, there are often many errors.

In this study the author uses the K-Means clustering method based on gray degree histogram to solve problems in grouping the quality of tuna meat. Clustring results obtained 3 groups of quality tuna fish meat which is Cluster A, Cluster B, Cluster C.

Keywords: clustering, quality tuna, K-Means

\section{PENDAHULUAN}

\subsection{Latar Belakang}

Potensi sumber daya perikanan dan kelautan Gorontalo yang paling menonjol adalah ikan tuna yang merupakan hasil tangkapan nelayan. Dinas Kelautan dan Perikanan (DKP) melakukan berbagai terobosan sehingga nelayan khususnya yang menangkap ikan tuna bisa sejahtera dengan tujuan untuk meningkatkan kualitas hasil perikanan (DKP, 2016).

Kualitas ikan tuna tangkapan nelayan Gorontalo memiliki kualitas dan mutu yang bagus, hal ini terlihat oleh banyaknya permintaan dari daerah tetangga. Saat ini produksi tuna hasil tangkapan nelayan di Gorontalo dikirim ke sejumlah daerah seperti Makassar, Surabaya, Jakarta, dan Bali. selanjutnya ikan tuna ini diekspor keluar negeri, hal ini disebabkan seringnya terjadi perbedaan dalam menentukan kualitas daging ikan tuna.

Dalam mengetahui mutu dan kualitas hasil perikanan, khusunya ikan tuna dapat dilihat secara langsung, tahapan ini dilakukan oleh seorang ahli (checker) dengan melakukan pembedahan pada ikan tuna. Ikan tuna akan dibedah menjadi empat bagian daging yaitu daging sisi kiri dan kanan. Namun dalam penentuan mutu dan kualitas daging ikan tuna dengan menggunakan cara ini sering terjadi banyak kesalahan.

Pada Tahapan pengelompokan kualitas daging ikan tuna terdiri dari tiga permasalahan 
utama yaitu pengambilan gambar, ekstraksi fitur da cluster. Pada tahap pengambilan gambar masih dilakukan dengan secara manual yaitu dengan meletakkan daging ikan tuna pada wadah kemudian kemudian diambil gambarnya dengan menggunakan kamera handphone.

Pada penelitian Pengelompokan kualitas kerja pegawai menggunakan algoritma K-Means++ dan Cop-Kmeans untuk merencanakan program pemeliharaan kesehatan pegawai di PT. PLN P2B JB Depok (Fikri, Agustin dan Mintarsih, 2017). Dari hasil penelitian, kualitas kerja dapat dikelompokkan dalam 5 kelompok dan tidak ada pegawai yang sama pada kelompok lain. Kecepatan perhitungan KMeans++ memang lebih lambat dibandingkan KMeans tetapi hasil K-Means++ lebih mendekati kebenaran dibandingkan K-Means.

Pada penelitian ini penulis menggunakan metode cluster yaitu K-Means dengan menggunakan histtogram derajat keabuan sebagai ekstraksi ciri.

\subsection{Rumusan Masalah}

Rumusan masalah pada penelitian ini mencakup dua hal:

1) Bagaimana menerapkan metode cluster $K$ Means?

2) Bagaimana performance dari K-Means ?

\subsection{Tujuan Penelitian}

1. Menerapkan metode cluster K-Means pada pengelompokan kualitas daging ikan tuna berbasis histogram derajat keabuan.

2. Menganalisis performance pengelompokan kualitas daging ikan tuna dengan parameter tingkat cluster kualitas daging ikan tuna.

\subsection{Manfaat Penelitian}

1. Metode K-Means lebih handal dalam pengelompokan kualitas daging ikan tuna.

2. Penggunaan Algoritma K-Means dapat meningkatkan performance pengelompokan kualitas daging ikan tuna.

\section{METODE PENELITIAN}

\subsection{Landasan Teori}

Ikan tuna adalah satu jenis ikan air laut yang banyak ditemukan dilautan dalam, ikan ini termasuk ikan laut pelagis yang termasuk kedalam famili Scombridae dengan ordo Perciformes. Ikan tuna ini memiliki bentuk tubuh menyerupai torpedo dengan sedikit pipih di bagian sisinya dan juga dengan mulut meruncing. Ikan ini memiliki sirip punggung dua berkas, pertama berukuran kecil da terpisah dengan sirip kedua.

Menurut Ka Hanjo (Tukang checker di Kelurahan Tanjung Kramat Kecamatan Hulonthalangi Kota Gorontalo) (Hanjo, 2016), Perbedaan kualitas daging ikan tuna akan di sajikan di Tabel 2.2.
Tabel 2.2. Kualitas daging ikan tuna

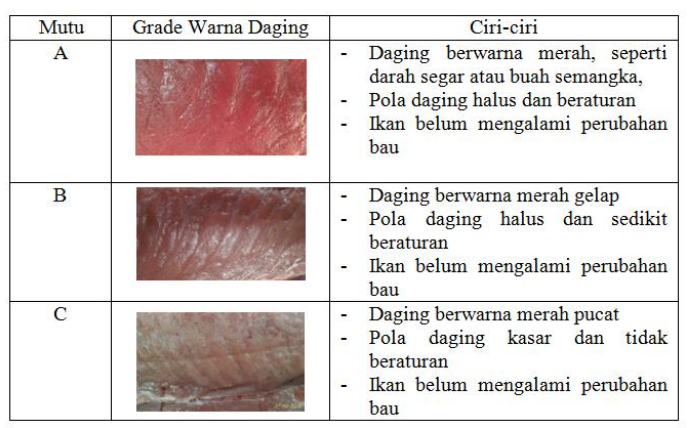

Ekstraksi fitur merupakan tahapan untuk memunculkan ciri dan mereduksi dimensi citra dari dimensi tinggi ke dimensi yang lebih rendah (Purnomo, Mauridhi, dan Muntasa, 2010). Dalam praktik, tekstur digunakan untuk berbagai kepentingan. Umumnya, aplikasi tekstur dapat dibagi menjadi dua kategori. Pertama adalah untuk kepentingan segmentasi. Pada proses ini, tekstur dipakai untuk melakukan pemisahan antara satu objek dengan objek yang lain. Kedua adalah untuk klasifikasi tekstur, yang menggunakan fitur-fitur tekstur untuk mengklasifikasi objek. Beberapa contoh aplikasi tekstur disajikan di bawah ini (Tuceryan dan Jain, 1998).

- Inspeksi secara otomatis pada industri tekstil, pengecatan mobil, pemakaian karpet.

- Analisis citra medis. Misalnya, tekstur digunakan untuk klasifikasi penyakit paru-paru, diagnosis leukemia, dan pembedaan tipe-tipe sel darah putih.

- Analisis penginderaan jarak-jauh. Misalnya, tekstur dipakai untuk kepentingan klasifikasi area tanah.

Dibawah ini merupakan formula dalam menentukan ekstraksi fitur tekstur (Kadir A. dan Susanto A. 2012).

rerata intensitas: $m=\sum_{i=0}^{L-1} i \cdot p(i)$

deviasi standar.: $\sigma=\sqrt{\sum_{i=1}^{L-1}(i-m)^{2} p(i)}$

skewness $=\sum_{i=1}^{L-1}(i-m)^{3} p(i)$

energi $=\sum_{i=0}^{L-1}[p(i)]^{2}$

entropi $=-\sum_{i=0}^{L-1} p(i) \log _{2}(p(i))$

$R=1-\frac{1}{1+\sigma^{2}}$ 
Data Mining sering juga disebut knowledge discovery in database (KKD), adalah kegiatan yang meliputi pengumpulan, pemakaian data historis untuk menemukan keteraturan, pola atau hubungan dalam set data berukuran besar. Keluaran data mining ini bisa dipakai untuk memperbaiki pengambilan keputusan dimasa depan berdasarkan informasi yang diperoleh dari data masa lalu (Santosa, 2007).

Data Mining merupakan proses menemukan pola dalam kumpulan data besar dengan menggunakan metode mesin learning, statistik, dan sistem basis data. Data mining merupakan sub disiplin ilmu komputer yang bertujuan untuk mengekstrak informasi dari kumpulan data dan mengubah informasi menjadi struktur yang dapat dipahami untuk digunakan. Data Mining merupakan langkah analisis proses dalam menemukan ilmu pengetahuan yang baru.

Data mining atau penambangan data sering diterapkan di segala bentuk data baik skala besar atau pemrosesan informasi (pengumpulan, ekstraksi, pergudangan, analisis, dan statistik) serta aplikasi sistem pendukung keputusan komputer (SPK), termasuk kecerdasan buatan.

Tugas data mining atau penambangan data yang sebenarnya adalah untuk menganalisis sejumlah besar data secara otomatis dan mengekstrak pola yang tidak diketahui sebelumnya. Pola ini kemudian dapat dilihat sebagai rangkuman input data dan dapat digunakan dalam analisis lebih lanjut atau, misalnya, dalam pembelajaran mesin dan analisis prediktif. Sebagai contoh, langkah data mining mungkin mengidentifikasi beberapa kelompok dalam data, yang kemudian dapat digunakan untuk memperoleh hasil prediksi yang lebih akurat oleh sistem pendukung keputusan. Baik pengumpulan data, persiapan data, maupun interpretasi hasil dan pelaporan merupakan bagian dari langkah data mining.

K-Means merupakan salah satu metode pengelompokan data nonhierarki (sekatan) ysng berusaha mempartisi data yang ada kedalam bentuk dua atau lebih kelompok. Metode ini mempartisi data kedalam kelompok sehingga data berkarakteristik sama dimasukkan kedalam satu kelompok yang sama dan data yang berkarakteristik berbeda dikelompokkan kedalam kelompok yang lain. Adapun tujuan pengelompokan data ini adalah untuk meminimalkan fungsi objektif yang diset dalam proses pengelompokan, yang pada umumnya berusaha meminimalkan variasi di dalam suatu kelompok dan memaksimalkan variasi antar kelompok (Prasetyo, 2012).

K-Means clustering adalah metode kuantisasi vektor yang berasal dari pemrosesan sinyal yang populer untuk analisis cluster dalam data mining. K-Means clustering bertujuan untuk mengelompokan $\mathrm{N}$ objek ke dalam klaster di mana setiap objek termasuk ke dalam cluster dengan jarak terdekat. K-Means clustering cenderung menemukan kelompok dengan tingkat spasial yang sebanding, sedangkan mekanisme penghitungan memungkinkan kelompok memiliki bentuk yang berbeda. Algoritma K-Means merupakan pembelajaran unsupervised learning. Inputan yang didapat merupakan data atau objek dan $k$ item kelompok (cluster) yang diinginkan. Metode ini akan membuat kelompok data atau objek ke dalam $k$ item kelompok tersebut. Pada setiap kelompok terdapat titik pusat (centroid) yang dipilih secara acak dari masing-masing cluster (Purnamaningsih, Saptono dan Aziz, 2014).

Perhitungan untuk mengetahui ruang jarak menggunakan Euclidean Distance dengan formula sebagai berikut:

$$
E\left(Y_{1}, Y_{2}\right)=\sqrt{\sum_{k=1}^{q}=\left|Y_{2 k}-Y_{1 k}\right|^{2}}
$$

E merupakan jarak antara data $Y_{2}$ dan $Y_{1}$ adalah nilai mutlak.

\subsection{Rancangan Tahapan Penelitian}

Adapun pola tahapan dalam penelitian ini adalah sebagai berikut:

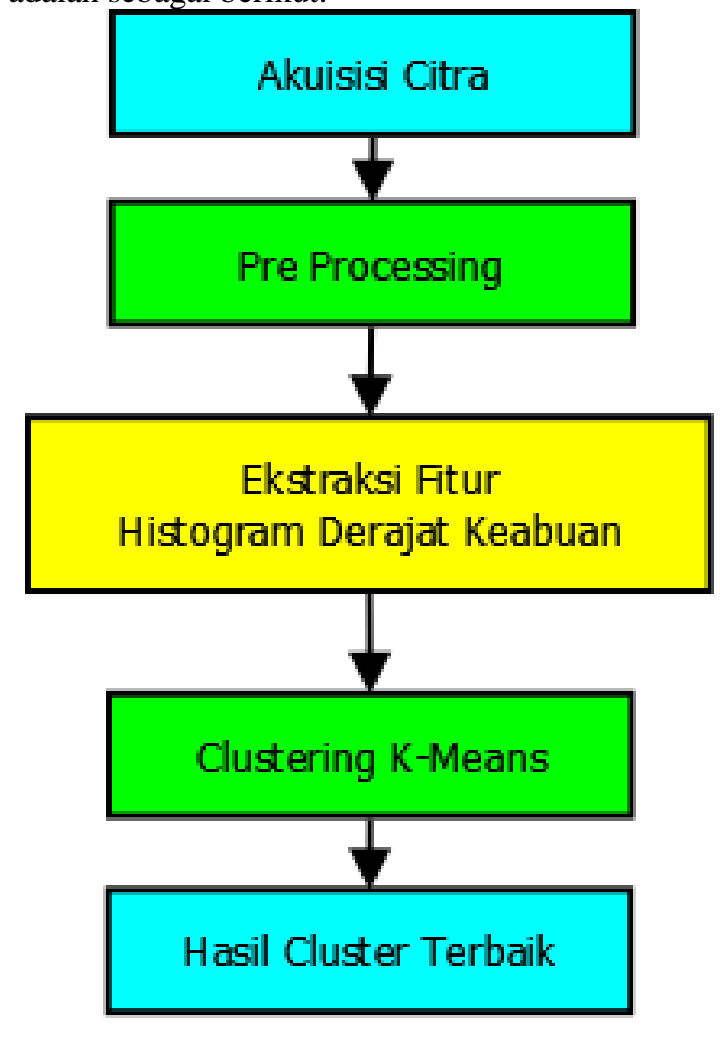

Gambar 3.1 Rancangan Penelitian

\subsection{Akuisi Citra}

Pengambilan citra dapat dilakukan antara lain dengan menggunakan kamera. Pengambilan citra dilakukan pada 90 objek daging tuna yang 
berbeda, ini bertujuan agar data yang didapatkan harus sesuai dengan apa yang diharapkan.

Adapun beberepa ketentuan dalam pengambilan citra daging ikan tuna:

a) Pencahayaan alami hampir selalu menjadi pilihan terbaik. Hindari menggunakan cahaya tambahan seperti blitz.

b) Penempatan subjek foto dalam posisi tengah, ini akan memberikan hasil yang maksimal dalam pengambilan citra daging ikan tuna.

c) Pada penangambilan citra daging ikan tuna sebaiknya menggunakan tripod. Kegunaan tripod antara lain:

- Tripod berfungsi untuk meningkatkan ketajaman pada hasil pengambilan citra.

- Tripod sangat diperlukan untuk komposisi angel atau aturan rule of third

- Tripod berfungsi untuk menahan guncangan saat pengambilan citra

- Tripod dapat membebaskan dari beban kamera apalagi jika kamera yang digunakan terlalu berat.

d) Sudut dan jarak pengambilan yang tepat sangat menentukan hasil pengambilan citra.

\subsection{Tahapan Preprocessing}

Preprocessing adalah proses pengolahan data asli sebelum data tersebut diolah dengan $K$ Means. Keuntungan preprocessing:

- Data lebih siap diolah dengan K-Means

- Fitur data lebih jelas

- Menghilangkan noise

Kerugian preprocessing:

- Perlu tambahan waktu komputasi sehingga pengolahan data secara keseluruhan lebih lama

- Algoritma preprocessing kadang-kadang menghilangkan informasi

Pada penelitian ini tahapan preprocessing yaitu menggunakan cropping untuk memotong gambar yang dianggap penting dalam tahapan clustering.

\subsection{Tahapan Ekstraksi Fitur}

Pada tahap ini di lakukan Ekstraksi ciri berbasis histogram. Ciri citra berdasarkan histogram antara lain: rerata intensitas, rerata kontras, standar deviasi, skewness, kurtosis, energy dan entropy.

\subsection{Tahapan Clustering}

Pengelompokkan kualitas daging dilakukan dengan menggunakan algoritma K-Means. Nilai diolah berdasarkan nilai asli ekstraksi fitur kemudian di cluster sehingga mendapatkan hasil. Adapun langkah-langkah $K$-Means:

1. Pilih $\mathrm{K}$ buah titik centroid secara acak

2. Kelompokkan data sehingga terbentuk $\mathrm{K}$ buah cluster dengan titik centroid dari setiap cluster merupakan titik centroid yang telah dipilih sebelumnya.
3. Perbarui nilai titik centroid.

4. Ulangi langkah 2 dan 3 sampai nilai titik centroid tidak lagi berubah.

Langkah - langkah proses clustering menggunakan algoritma K-Means dapat di implementasikan di Gambar 3.2.

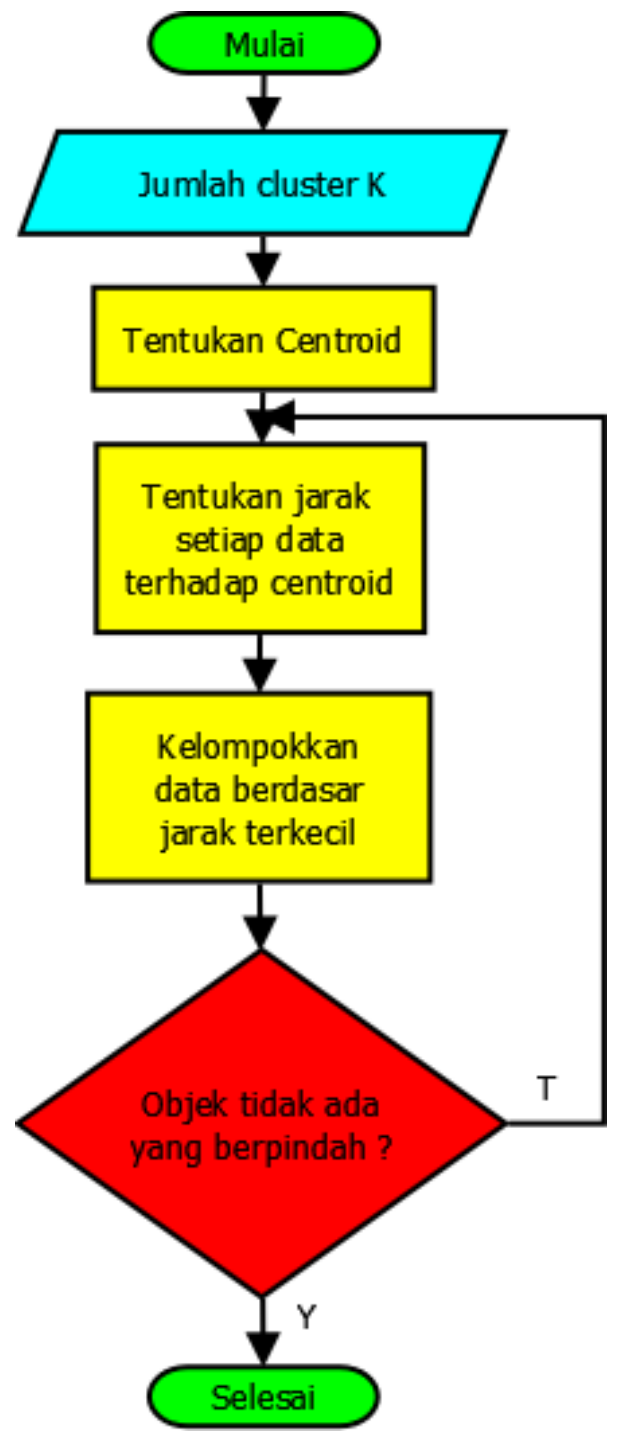

Gambar 3.2 Proses clustering K-Means

\section{HASIL DAN PEMBAHASAN}

\subsection{Pengambilan Gambar Daging Ikan Tuna}

Pengambilan gambar daging ikan tuna merupakan proses awal dengan menggunakan kamera dengan kualitas minimal 20 megapixel. Proses pengambilan gambar daging ikan tuna diambil pada jarak antara $15 \mathrm{~cm}$ dan $20 \mathrm{~cm}$ tidak menggunakan bantuan cahaya handphone (blitz). Hasil pengambilan gambar berupa gambar warna (RGB) dengan resolusi 4096×2304 pixel. 


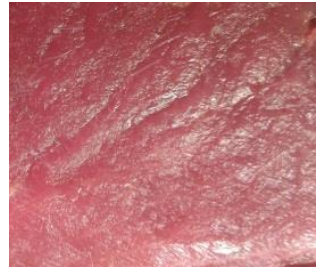

Gambar 4.1 Daging ikan tuna

\subsection{Pre Processing}

Penelitian ini menggunakan gambar daging ikan tuna dengan jumlah 90 gambar daging ikan tuna dengan kualitas yang berbeda yang semuanya diambil langsung dari tempat pelelangan ikan (TPI) di Gorontalo.

\subsection{Ekstraksi ciri berdasarkan tekstur}

Contoh perbandingan statistik tekstur untuk citra daging ikan tuna dengan histogram derajat keabuan ditunjukan di Tabel 4.4.

Tabel 4.4 Fitur ekstraksi tekstur

\begin{tabular}{|l|ll|}
\hline Daging ikan tuna & \multicolumn{2}{|c|}{ Fitur } \\
\hline & Rerata intensitas & $: 136.358307231041$ \\
& Rerata kontras & $: 48.5096919211455$ \\
& Skewness & $: 0.463316877385731$ \\
& Energi & $: 0.00581876976742595$ \\
& Entropi & $: 5.21588851808668$ \\
& Smootness & $: 0.0349251026621559$ \\
\hline
\end{tabular}
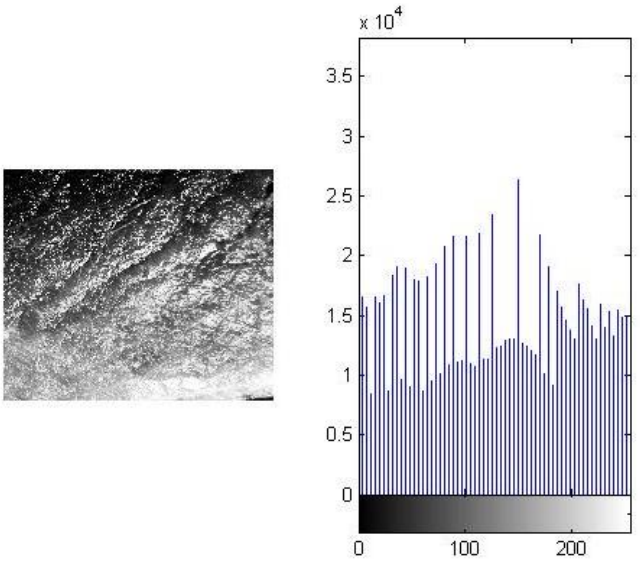

Gambar 4.2 Histogram citra daging ikan tuna

Gambar 4.2 menunjukan bahwa citra dengan tekstur kasar, ditandai kontras yang tinggi dan jangkauan intensitas yang rapat. Percobaan pertama dilakukan pada masing-masing fitur pada citra tekstur terhadap nilai rerata intensitas, rerata kontras, skewness, energy, energy dan smootness. Hasil percobaan ditunjukkan pada Gambar 4.3

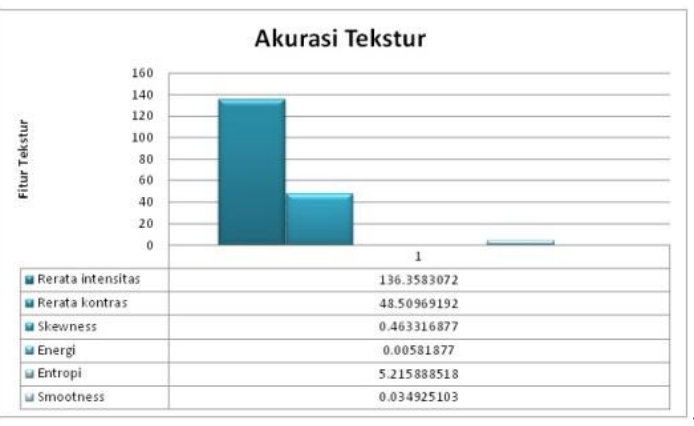

Gambar 4.3 Akurasi Tekstur daging ikan tuna

Gambar 4.3 menunjukkan bahwa akurasi berdasarkan ekstraksi fitur tekstur tertinggi adalah fitur rerata intensitas, sedangkan akurasi terendah adalah fitur energy.

\subsection{Analisis Hasil K-Means}

Di bawah ini merupakan tahapan pengoprasian dari algoritma $K$-Means :

Diketahui :

$\begin{array}{ll}\text { Jumlah Clsuter } & =3 \\ \text { Jumlah data } & =90 \\ \text { Jumlah atribut } & =6\end{array}$

Tabel 4.12 Sampel data ekstraksi fitur daging ikan tuna

\begin{tabular}{|c|c|c|c|c|c|c|}
\hline No & $\begin{array}{c}\text { Rerata } \\
\text { Intenstas }\end{array}$ & $\begin{array}{c}\text { Rerata } \\
\text { Kontras }\end{array}$ & Skewness & Energi & Entropi & Smootness \\
\hline K1 & 140.4073 & 42.79766 & 0.184848 & 0.006489 & 5.125613 & 0.027397 \\
\hline K2 & 129.3492 & 44.69915 & 0.37992 & 0.007396 & 5.033309 & 0.029811 \\
\hline K3 & 135.5919 & 41.68422 & 0.303849 & 0.007826 & 4.976353 & 0.026026 \\
\hline K4 & 121.0984 & 48.27204 & 0.353883 & 0.006064 & 5.188368 & 0.034596 \\
\hline K5 & 125.2385 & 54.36881 & 0.05849 & 0.005406 & 5.313721 & 0.043482 \\
\hline K6 & 137.6999 & 45.86221 & -0.00274 & 0.006112 & 5.193771 & 0.031333 \\
\hline K7 & 139.7271 & 42.88566 & 0.186687 & 0.007272 & 5.069261 & 0.027506 \\
\hline K8 & 130.1291 & 48.22397 & 0.057944 & 0.005726 & 5.235261 & 0.034529 \\
\hline K9 & 139.2189 & 49.12214 & 0.128868 & 0.00627 & 5.17526 & 0.035781 \\
\hline K10 & 136.3583 & 48.50969 & 0.463317 & 0.005819 & 5.215889 & 0.034925 \\
\hline K11 & 121.9692 & 41.81942 & 0.485925 & 0.008364 & 4.929944 & 0.026191 \\
\hline K12 & 113.3409 & 49.13902 & 1.051754 & 0.010641 & 4.80244 & 0.035805 \\
\hline K13 & 119.129 & 38.82565 & 0.496151 & 0.011081 & 4.700871 & 0.022657 \\
\hline K14 & 118.4369 & 44.98947 & 0.782622 & 0.01168 & 4.709488 & 0.030188 \\
\hline K15 & 115.2238 & 38.75521 & 0.52871 & 0.011141 & 4.714961 & 0.022577 \\
\hline K16 & 126.0747 & 37.90199 & 0.310476 & 0.008504 & 4.880904 & 0.021615 \\
\hline K17 & 133.11 & 54.55545 & 0.321178 & 0.005268 & 5.322353 & 0.043768 \\
\hline K18 & 124.4998 & 46.68842 & 0.786517 & 0.015597 & 4.519607 & 0.032435 \\
\hline K19 & 151.1044 & 44.91586 & 0.49237 & 0.008337 & 4.932098 & 0.030092 \\
\hline & & & & & & \\
\hline & & & & & & \\
\hline K90 & 116.6531 & 47.58086 & 0.436287 & 0.006002 & 5.203307 & 0.033645 \\
& & & & & & \\
& & & & & \\
\hline
\end{tabular}

Iterasi ke-1

1. Penentuan pusat awal cluster

\begin{tabular}{|l|r|r|r|r|}
\hline Di ambil data ke-1 sebagai pusat cluster ke-1 & 140.4073 & 42.79766 & 0.184848 & 0.006489 \\
\hline Di ambil data ke-30 sebagai pusat cluster ke-2 & 76.08399 & 27.74613 & 0.51084 & 0.013774 \\
\hline Di ambil data ke-60 sebagai pusat cluster ke-3 & 137.3911 & 30.9636 & 0.209335 & 0.009654 \\
\hline
\end{tabular}

2. Perhitungan jarak pusat clsuter

Dalam perhitungan jarak pusat cluster menggunakan Euclidian Distance. Dari perhitungan akan didapatkan matriks jarak yaitu C1, C2 dan C3 sebagai berikut:

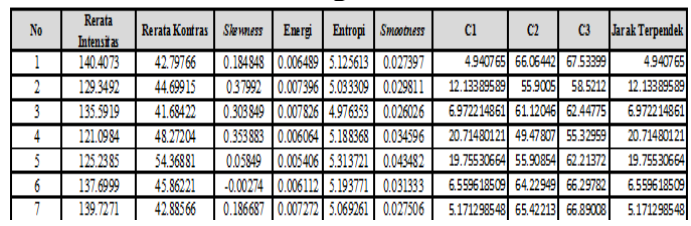


3. Pengelompokan data

Dari jarak hasil perhitungan lalu akan dilakukan perbandingan dan dipilih jarak terdekat antara data dengan pusat cluster, jarak ini menunjukkan bahwa data tersebut berada dalam satu group dengan pusat cluster terdekat. Dibawah ini merupakan data matriks pengelompokkan group, nilai 1 berarti data tersebut berada dalam group (kelompok data).

\begin{tabular}{|c|c|c|c|}
\hline No. & C1 & C2 & C3 \\
\hline 1 & 0 & 0 & 1 \\
\hline 2 & 1 & 0 & 0 \\
\hline 3 & 1 & 0 & 0 \\
\hline 4 & 0 & 1 & 0 \\
\hline 5 & 0 & 1 & 0 \\
6 & 1 & 0 & 0 \\
\hline 7 & 0 & 0 & 1 \\
\hline
\end{tabular}

4. Penentuan pusat cluster baru

Tahapan selanjutnya yaitu membuat pusat cluster baru. Setelah diketahui anggota tiap-tiap cluster lalu pusat cluster baru dihitung berdasarkan data anggota tiap-tiap cluster.

Iterasi ke-2

5. Ulangi langkah ke 2 (kedua) hingga posisi data tidak mengalami perubahan.

Untuk melakukan uji coba dalam memperoleh jumlah $\mathrm{k}$ terbaik, jumlah cluster yang akan diuji adalah dari $\mathrm{K}=2$ sampai dengan $\mathrm{K}=7$. Dari hasil pengujian diperoleh variasi terbaik pengelompokkan kualitas daging ikan tuna dengan metode K-Means sebanyak 3 cluster. Hasil pengujian akan disajikan pada table 4.13.

Tabel 4.13 Hasil SSE (Sum of Square Error) dari tiap-tiap cluster.

\begin{tabular}{|c|c|c|}
\hline Cluster & Hasil SSE & Selisih \\
\hline K2 & -3.484 & -3.484 \\
\hline K3 & -2.849 & -0.635 \\
\hline K4 & -2.265 & -0.584 \\
\hline K5 & -1.985 & -0.28 \\
\hline K6 & -1.548 & -0.437 \\
\hline K7 & -1.39 & -0.158 \\
\hline
\end{tabular}

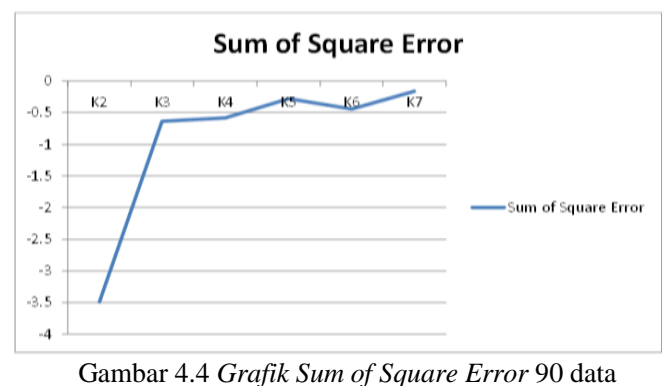

Untuk memperoleh memperoleh cluster terbaik dapat menggunakan metode Elbow dimana untuk menghasilakn informasi dalam menentukan jumlah cluster terbaik dengan cara melihat persentase hasil perbandingan antara jumlah cluster yang membentuk siku pada suatu titik.

\section{KESIMPULAN DAN SARAN}

Dengan melakukan penelitian terhadap Pengelompokkan kualitas daging ikan tuna dengan $K$-Means berbasis histogram derajat keabuan dapat disimpulkan:

1. Metode K-Means sangat baik untuk pengelompokkan kualitas daging tuna.

2. Hasil pengelompokkan kualitas daging ikan tuna dengan menggunakan metode $K$-Means berbasis histogram derajat keabuan sebanyak 90 data, diperoleh 3 cluster kualitas daging ikan tuna yaitu Cluster A, Cluster B dan Cluster C.

Saran dari penelitian pengelompokkan kualitas daging ikan tuna dengan $K$-Means berbasis histogram derajat keabuan:

1. Proses pengambilan gambar atau citra dibuat sebaik mungkin, hal ini bertujuan supaya hasil klasifikasi dalam pengenalan akan lebih baik.

2. Untuk keberlanjutan penelitian dapat menggunakan metode cluster yang lain, untuk mendapat tingkat akurasi yang lebih baik.

\section{DAFTAR PUSTAKA}

Dinas Kelautan dan Perikanan Provinsi Gorontalo. (2016) "Buku Profil Provinsi Gorontalo" Gorontalo: BAPPEDA Provinsi Gorontalo.

Fikri, M.C., Agustin, M.E.F., \& Mintarsih F. (2017). Pengelompokan kualitas kerja pegawai menggunakan algoritma K-Means++ dan Cop-Kmeans untuk merencanakan program pemeliharaan kesehatan pegawai di pt. Pln p2b jb depok. Jurnal Pseudocode, 4(1), 9-17.

Hanjo, K. (2016). "Laporan Pengabdian Masyarakat" Gorontalo: Perpustakaan Politeknik Gorontalo.

Kadir, A. \& Susanto, A., (2012). "Teori dan Aplikasi Pengolahan Citra" Yogyakarta: Andi.

Purnamaningsih, C., Saptono, R., \& Aziz, A. (2014). Pemanfaatan Metode K-Means Clustering dalam Penentuan Penjurusan Siswa SMA. Jurnal Itsmart, 3(1), 27-33.

Purnomo, M.H, \& Muntasa, A. (2010). "Konsep Pengolahan Citra Digital dan ekstraksi Fitur" (Ed. 1) Yogyakarta: Graha Ilmu.

Prasetyo, E. (2012). "Data Mining Konsep dan Aplikasi menggunakan Matlab" (Ed. 1) Yogyakarta: Andi.

Santosa, B. (2007). "Data Mining Terapan Dengan Matlab" (Ed. 1). Yogyakarta: Graha Ilmu.

Tuceryan, M., \& Jain, K.A., (1998). Texture Analysis. On Handbook of Pattern Recognition and Computer Viision (pp. 207 248). New York: Word Scientific Publishing Company 